\title{
The RCEP and Its Investment Rules: Learning from Past Chinese FTAs
}

\author{
Heng Wang \\ Associate Professor and Co-Director of CIBEL (China International Business \\ and Economic Law) Initiative, Faculty of Law, The University of New South \\ Wales, Sydney, Australia; University Visiting Professorial Fellow, Southwest \\ University of Political Science and Law, China \\ heng.wangı@unsw.edu.au
}

\begin{abstract}
China's free trade agreements (FTAs) reveal malleability as the most striking feature. The paper analyzes the following questions: what is the trend of China's FTA approach to investment concerning malleability? Is China a rule follower, shaker or maker? How may China approach the Regional Comprehensive Economic Partnership (RCEP) regarding investment? It argues first that the malleability will probably expand from investment protection to investment liberalization. China converges with deep FTAs regarding investment protection and may incrementally move to investment liberalization. Second, increased malleability of China's FTAs exists in regulatory autonomy and investor-state dispute settlement. Third, China is likely to be a rule shaker in the short to medium term, and become a rule maker later if challenges are addressed. Its approach may evolve from selective adaption to selective innovation. Finally, the RCEP may adopt low-level investment rules and an early harvest approach due to, inter alia, existing agreements and the nature of mega FTA.
\end{abstract}

\section{Keywords}

RCEP - investment - China - FTAs - malleability - selective innovation

* I am grateful to the insightful comments of Markus Wagner, Jyh-An Lee, Cristián Rodríguez Chiffelle, Joel Slawotsky, and other participants of the Asian FDI Forum 2016, and the assistance of Melissa Vogt. Special thanks go to Julien Chaisse for the invitation to speak at Asian FDI Forum. Any errors or oversights are my own.

(C) WANG, HENG, 2017 | DOI 10.1163/23525207-12340026

This is an open access article distributed under the terms of the Creative Commons Attribution- 


\section{Introduction}

The growth of China's outbound investment has been phenomenal in the past decade, and China's FTAs ${ }^{1}$ are an effective channel for developing the investment rules of China. China has actively worked towards facilitating investment. As a most recent example, the G2o Trade and Investment Working Group was set up in 2016, based on China's proposal. ${ }^{2}$ Resulting from the discussions in this Working Group, the G2o Guiding Principles for Global Investment Policymaking ${ }^{3}$ were issued under the Chinese G2o Presidency. ${ }^{4}$ At the time of writing, China has concluded 14 FTAs with 22 countries and regions, ${ }^{5}$ nearly all of which contain investment provisions. Investment rules of these FTAs not only involve investment protection, promotion, and facilitation, but also concern domestic reform such as the free trade zones (FTZs). Moreover, a few FTAs are being negotiated, with several FTAs to be upgraded. Among China's FTAs under negotiation, the RCEP is the only mega FTA to which China is a party. It has been actively promoted by China. The RCEP investment rules are likely to significantly affect China's investment regime, and deserve careful study.

For China's FTAs including their investment rules, malleability is their most noticeable and core characteristic. It is observed that "[a]fter a decade, the greatest defining feature of Chinese FTAs is their malleability." ${ }^{\prime 2}$ The malleability can be easily found in investment chapters of China's recent FTAs with Australia and Korea. Likely in order to finalize the treaty, the China-Australia FTA (ChAFTA) only contains an early harvest investment chapter. Unlike the China-Korea FTA, a number of key provisions (e.g. the minimum standard of

1 It is probably more accurate to use the term of preferential trade agreements (PTAS) as these agreements are regulated rather than free trade. However, the term of FTAs is used to be consistent with the official titles of many of these trade pacts. Past Chinese FTAs refer to the FTAs that China has signed until now.

2 Xinhua, G2o trade ministers to meet in Shanghai in July (2016), available at http://usa .chinadaily.com.cn/china/2016-02/17/content_23527532.htm.

3 G2o Guiding Principles for Global Investment Policymaking (2016), available at http://www .oecd.org/daf/inv/investment-policy/G2o-Guiding-Principles-for-Global-InvestmentPolicymaking.pdf.

4 oecd, G2o agrees Guiding Principles for Global Investment Policymaking(2016), available at http://www.oecd.org/investment/g2o-agrees-principles-for-global-investment-policy making.htm.

5 China FTA Network, http://fta.mofcom.gov.cn.

6 Jun Zhao \& Webster Timothy, Taking Stock: China's First Decade of Free Trade, 33 University of Pennsylvania Journal of International LaW 65, 99 (2011). 
treatment, performance requirements, expropriation, compensation, transfers, and services-investment linkage) are missing in the ChAFTA and need to be developed in future negotiations.

The paper will analyze China's FTA approach to investment in terms of malleability, and its implications for the RCEP. The following questions will be discussed: what is the trend of China's FTA approach to investment concerning malleability? Is China a rule follower, shaker or maker? How may China approach the RCEP regarding investment?

Within China's FTAs, the paper will focus on the China-Korea FTA and ChAFTA, while other China's FTAs will be referred to when needed. On the one hand, these two agreements are larger pacts that reflect China's latest treaty practice, and all three countries are RCEP parties. These agreements are likely to affect the RCEP. On the other hand, Australia and Korea appear to be affected by the US approach through the TPP or trade agreements with the US. Australia is a party to the Trans-Pacific Partnership (TPP) and concluded an FTA with the Us. Korea concluded the Us-Korea Trade Agreement (KORUs) and was interested in joining the TPP. Interestingly, the China-Korea FTA contains a few clauses that resemble those of the KORUS, and the KORUS is "widely

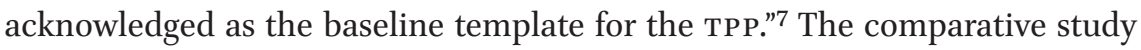
of China's trade agreements with Korea and Australia may help to observe the possible interaction between Chinese and American approaches.

To better understand China's approach in the context of world investment law recalibration, the paper also strives to compare China's FTAs with two deep FTAs: ${ }^{8}$ the Trans-Pacific Partnership (TPP) and the EU-Canada Comprehensive Economic and Trade Agreement (CETA). Notably, some RCEP parties (e.g. Australia, Japan, and New Zealand) negotiated the TPP, and the TPP text may affect the RCEP talks. Although the Us withdrew from the TPP, it is unlikely that the Us will dramatically change its position on investment rules. The TPP is based on previous us practice and primarily reflects the us approach to investment. These deep FTAs could serve as a kind of "benchmark" 9 for the comparison in this paper. The comparative analysis helps to better understand

7 Gary Clyde Hufbauer, Investor-State Dispute Settlement, in Assessing the Trans-Pacific Partnership, Volume 1: Market Access and Sectoral Issues 117, (2016).

8 "Deep" FTAs are those agreements with stringent wTO-extra regulatory requirements that go substantially beyond the WTо norms. They contrast with traditional FTAs that largely copy the wто rules with few novel regulatory disciplines.

9 This paper does not assess the substantive merits of these provisions. That is a complex subject that requires separate and extensive treatment. 
the similarities and differences among the approaches of China, the Us, and $\mathrm{EU}$, which is important for exploring the future direction of investment law.

Section 2 will discuss the possible extension of China's investment rule malleability from investment protection to investment liberalization, and Section 3 will analyze China's increased malleability on regulatory autonomy and investor-state dispute settlement (ISDS). Section 4 will assess China's role in investment rulemaking, followed by Section 5 which will predict the impact of China's approach to the RCEP. Section 6 concludes.

Extended Malleability of China's Investment Rules: From Investment Protection to Investment Liberalization?

Up to now, the non-malleability of China's FTA investment rules exists regarding the avoidance of investment liberalization commitments. Deep FTAs highlight investment protection and liberalization. However, China's trade pacts focus on investment protection, but do not provide for investment liberalization.

In the future, China may progressively move towards investment liberalization at least to some extent. The progress regarding pre-establishment national treatment and negative list approach is likely to continue regardless of the difficulties of the TPP and the uncertainty of US-China bilateral investment treaty (BIT) negotiations under the new Us administration. Such efforts have already been conducted widely in the FTzs and beyond (e.g. the domestic law change to promote negative list approach, ${ }^{10}$ and the future work plan of China's FTAS with Australia and Korea).

\subsection{Investment Protection}

Substantial malleability can be seen as the China-Korea FTA is quite different from short form ChAFTA rules. On the one hand, the China-Korea FTA resembles deep FTAs and in particular the TPP in most aspects of investment protection, with some exceptions (e.g. performance requirements, the standard of compensation in expropriation and the scope of MFN treatment). Highlighting investment protection, the China-Korea FTA seems to align with the TPP in a number of aspects, including the minimum standard of treatment, expropriation and compensation, special formalities and information requirements, the transfer of capital, and non-discriminatory treatment of investors and investments in cases of armed conflict or civil strife.

10 Xinhua, China revises inbound investment laws (2016), available at http://news.xinhuanet .com/english/2016-09/03/c_13565736o.htm. 
For the minimum standard of treatment, the China-Korea FTA adopts a nearly identical provision with the TPP, ${ }^{11}$ but differs from the CETA that incorporates an unclear but exhaustive definition of the fair and equitable treatment (FET) obligation. ${ }^{2}$ Both the TPP and China-Korea FTA contain a FET provision, but set its scope as limited to treatment available under customary international law. ${ }^{13}$ Moreover, they provide that the breach of another provision of this pact or other agreement will not entail a violation of the FET rule. ${ }^{14}$ Notably, the limitations placed on the FET obligation represent a consistent practice in China's recent investment agreements (e.g. China's BITs with Mexico and Canada, and the China-Korea-Japan Investment Agreement) and ASEAN investment treaties particularly those with Australia, New Zealand, and Korea. ${ }^{15}$ Such practice continues in the China-Korea FTA, ${ }^{16}$ which arguably provides stronger protection than China's other recent treaties. The China-Korea FTA is the same as the TPP in the sense of stronger protection by providing for treatment "including" FET and full protection and security (FPS). ${ }^{17}$ As two recent investment treaties, the China-Canada BIт $^{18}$ and China-Japan-Korea Investment Agreement ${ }^{19}$ only provide for FET and FPS.

Regarding expropriation and compensation, the China-Korea and ChinaNew Zealand FTAS ${ }^{20}$ largely resemble deep trade agreements, ${ }^{21}$ including the criteria of the fair market value of the expropriated investments. For indirect expropriation, the China-Korea FTA has nearly identical wording with the TPP, ${ }^{22}$ and is mostly similar to the CETA. ${ }^{23}$ Concerning special formalities and information requirements, the China-Korea FTA also finds parallels in the

\footnotetext{
11 China-Korea FTA Article 12.5; TPP Articles 9.6 (Minimum Standard of Treatment), 9.7 (Treatment in Case of Armed Conflict or Civil Strife).

12 CETA Article 8.10.2.

13 China-Korea FTA Article 12.5.2; тPP Article 9.6.2.

14 China-Korea FTA Article 12.5.3; TPP Article 9.6.3.

15 Mark Feldman, et al., The Role of Pacific Rim FTAs in the Harmonisation of International Investment Law: Towards a Free Trade Area of the Asia-Pacific 10 (2016), available at http:// e15initiative.org/wp-content/uploads/2015/og/E15-Investment-Feldman-MonardesRodriguez-Chiffelle-Final.pdf.

16 China-Korea FTA Articles 12.5.2 (FET obligations), 12.15 (denial of benefits). 2015.

17 Id. at Article 12.5.1; TPP Article 9.6.1.

18 China-Canada BIT Article 4.1.

19 China-Japan-Korea Investment Agreement Article 5.1.

20 China-Korea FTA Article 12.9; China-New Zealand fTA Article 145.

21 TPP Article 9.8; CETA Article 8.12.

22 China-Korea FTA Annex 12-B, paragraph 3; TPP Annex 9-B, paragraph 3.

23 CETA Annex 8-A.
} 
TPP. ${ }^{24}$ The CETA has a concise provision on formal requirements, ${ }^{25}$ but omits the provision on special formalities connected with a covered investment in the TPP and the China-Korea FTA. ${ }^{26}$ In terms of subrogation, the positions of these three agreements are alike, but the China-Korea FTA sets out more detailed rules than the CETA and TPP. ${ }^{27}$

On the other hand, the ChAFTA markedly differs from the China-Korea FTA regarding investment protection, and is unique concerning the heavy reliance on non-discrimination clauses, particularly the MFN treatment obligation. The ChAFTA incorporates only limited investment treatment provisions (mainly national treatment and MFN treatment), and contains the explicit plan to address most remaining issues in future negotiations (e.g. the minimum standard of treatment, expropriation, transfers, performance requirements, senior management and board of directors ${ }^{28}$ ). On the one side, the ChAFTA MFN treatment provision covers the pre-establishment and post-establishment phases, and enables investors to benefit from better treatment under future agreements. ${ }^{29}$ This MFN provision does not exclude all the FTAs from its scope as does the China-Korea FTA. ${ }^{30}$ Only the treatment to investors under "bilateral or multilateral international agreement" in force before the effective date of the ChAFTA, including their subsequent review or amendment, is excluded from the MFN. ${ }^{31}$ As with the China-New Zealand FTA, ${ }^{32}$ it ensures that investors and investment in the free trade area will benefit from the treatment under future agreements concluded by the treaty parties. These agreements should include the Us-China and China-EU BITs, if everything goes smoothly. On the other side, the ChAFTA lacks provisions such as an FET obligation that are most commonly invoked by investors in the ISDS proceedings. The ChAFTA works with the China-Australia BIT regarding investment protection. Although the BIT entered into force in 1988 and is out-of-date, it provides for,

\footnotetext{
24 China-Korea FTA Article 12.13; TPP Article 9.14.

25 CETA Article 8.17.

26 China-Korea FTA Article 12.13.1; TPP Article 9.14.1.

27 China-Korea FTA Article 12.11; CETA Article 8.14; TPP Article 9.13.

28 ChAFTA Article 9.9.3(b).

29 Id. at Article 9.4.1.

$30 \quad$ China-Korea FTA Article 12.4.2(a).

31 ChAFTA Article 9.4.3.

32 China-New Zealand FTA Articles 139.1, 139.3.
} 
among other things, FET, ${ }^{33}$ expropriation, ${ }^{34}$ transfers, ${ }^{35}$ and the adherence to written undertakings given to investors. ${ }^{36}$

The ChAFTA rules will probably converge with deep FTAs concerning investment protection. The MFN treatment provision, which the ChAFTA depends crucially on, and Australian commitments on national treatment already bear close resemblance to the TPP counterpart. ${ }^{37}$ Moreover, Australia is a TPP party, and China's other recent agreement with Korea is close to the TPP in investment protection. All these factors lay the foundation for possible convergence.

\subsection{Investment Liberalization}

China's FTAs rarely deal with investment liberalization on the part of China, which contrasts with the us approach. This finding also holds true for China's investment treaties. The 2012 China-Canada BIT, as one of the most recent China's BITs, lacks a commitment to investment liberalization. ${ }^{38}$ As with China's FTAs with Australia and Korea, the China-ASEAN FTA focuses on investment protection rather than investment protection and liberalization in Japan's economic partnership agreements with single ASEAN members. ${ }^{39}$ Even though the ChAFTA contains basic market access provisions, most of them deal with the obligations of Australia. China's FTAs neither include investment schedules of China nor contain the provision on market access in FTAs as the case with the CETA. ${ }^{40}$

In China's FTAs, national treatment obligations only apply to the post-establishment stage of investment. In the ChAFTA, China's national treatment obligations do not extend to "establishment, acquisition" or "the establishment or acquisition of a new, separate investment". 41 The absence of these terms avoids market access obligations, partially because investment liberalization involves challenging regulatory issues. In contrast, some of China's FTAs oblige parties

\footnotetext{
33 China-Australia Bit Article III(a).

34 Id. at Article viII.

35 Id. at Article $\mathrm{x}$.

36 Id. at Article XI.

37 ChAFTA Articles 9.3, 9.4; TPP Articles 9.4, 9.5.

38 Axel Berger, Investment Rules in Chinese Preferential Trade and Investment Agreements: Is China following the global trend towards comprehensive agreements? at https://www.diegdi.de/uploads/media/DP_7.2013.pdf.

39 Julien Chaisse, The Shifting Tectonics of International Investment Law-- Structure and Dynamics of Rules and Arbitration on Foreign Investment in the Asia-Pacific Region, 47 George Washington International LaW Review 563, 615-616 (2015).

40 CETA Article 8.4.

41 ChAFTA Article 9.3.2, footnote 1.
} 
to provide MFN treatment at pre-establishment and post-establishment stages, including China's FTAs with the ASEAN ${ }^{42}$ and Australia. ${ }^{43}$ However, these MFN treatment clauses do not impose stringent requirements regarding investment liberalization.

That said, China is progressively heading towards investment liberalization, possibly first in the US-China BIT and China's agreements with advanced economies, and then in other FTAs. Overall, such a plan focuses on a pre-establishment national treatment on the basis of a negative list. The move appears to be primarily driven by the Us-China BIT negotiations, in which China recently offered a more open negative list offer than in FTZs regarding several key sectors (e.g. banking, securities, insurance, telecommunications, culture, internet, and autos) ${ }^{44}$ Moreover, China is moving towards investment liberalization by the amendment of the municipal law to promote the negative list approach, ${ }^{45}$ and the development prospect of China's FTAs with Australia and Korea. For the latter, a key component of the ChAFTA forward work program is China's commitments on market access, which may be connected with US-China BIT negotiations. In the future, national treatment obligations under China's FTA investment rules will extend from established investments to the pre-establishment stage. Meanwhile, the design of negative list needs to be addressed, which remains a crucial issue in the Us-China BIT negotiations.

Why might China move towards investment liberalization? First, as probably the most important reason, investment liberalization will benefit Chinese overseas investment. As a major capital importer and exporter, China has balanced and neutral interests regarding outbound and inbound investment. In fact, China's businesses investing overseas have repeatedly called for the Chinese government to incorporate the pre-establishment national treatment into the investment treaty. ${ }^{46}$ The FTAS of China may need to respond more efficiently to the needs of businesses participating in the global value chain. Second, investment liberalization helps to attract foreign investment and boost investor confidence in China, which is crucial for the economic development. Last but not least, investment liberalization may facilitate domestic reform in China.

\footnotetext{
42 China-ASEAN Investment Agreement Article 5.1.

43 ChAFTA Article 9.4.1.

44 Zhang Yuanan, Wang Yang: Sino-US Cooperation is the Only Right Choice, Caixin (2016), available at http://international.caixin.com/2016-11-23/101010192.html.

45 Xinhua, China Revises Inbound Investment Laws (2016), available at http://news.xinhua net.com/english/2016-09/o3/c_13565736o.htm.

46 Xiantao Wen, Review of China's Model Investment Protection Treaty (Draft): Part I, 18 Chinese Journal of International Economic LaW 169, 172 (2012).
} 


\section{Increased Malleability of China's Investment Rules: Regulatory Autonomy and ISDS}

Compared with other investment norms, more malleability of China's investment rules could be found in IsDs and regulatory autonomy. Relevant provisions are rather different between China's trade pacts with Australia and Korea, although they overall take a similar approach to investment and were signed on the same date.

\subsection{Regulatory Autonomy}

More malleability can be seen concerning regulatory autonomy in China's recent FTAS, which arguably converge with the TPP and CETA regarding basic safeguards to retain policy space. The theme of investment rules remains the balance between investment protection and the right to regulate. ${ }^{47}$ The increased malleability is understandable in the sense that the deference to regulatory autonomy is easy to be accepted by governments as they provide regulators with more room. Like other trade agreements, the ChAFTA strives to protect regulatory space through provisions on general exceptions, nonconforming measures, and the denial of benefits. Taking the provision on denial of benefits as an example, the ChAFTA has an identical provision with the TPP, ${ }^{48}$ and the China-Korea FTA also takes a similar position. These FTAS are essentially alike by mainly targeting shell companies and the investor that is an enterprise owned or controlled by persons of a non-party or the denying party. ${ }^{49}$ The denial of benefits provision is utilized to avoid forum shopping through establishing shell companies. ${ }^{50}$ Moreover, these agreements explicitly address the circumvention of the measures adopted by the denying party. ${ }^{51}$ The CETA adopts a similar approach to the denial of benefits but adds the consideration for the maintenance of international peace and security. ${ }^{52}$ Despite these similarities, more malleability is evident regarding regulatory autonomy.

The China-Korea FTA provides a weaker safeguard for the right to regulate than the ChAFTA. The China-Korea FTA is more similar to the TPP, and

47 For the analysis of regulatory space, see, e.g. Markus Wagner, Regulatory Space in International Trade Law and International Investment Law, 36 UNIVERsity of PENNSYlVANia Journal of International LAW 1, 1-87 (2014).

48 ChAFTA Article 9.6; TPP Article 9.7.

49 ChAFTA Article 9.6.1; China-Korea FTA Article 12.15.2; TPP Article 9.15.1.

$50 \quad$ China-Korea FTA Article 12.15; ChAFTA Article 9.6; TPP Article 9.15.1(b).

51 ChAFTA Article 9.6; China-Korea FTA Article 12.15.1(b); TPP Article 9.15.2.

$5^{2}$ CETA Article 8.16(b)(i). 
both only recognize the right to regulate regarding narrow or isolated issues (indirect expropriation or few performance requirements). In contrast, the ChAFTA is closer to the CETA, and they defer more to regulatory autonomy than the China-Korea FTA and TPP. Compared with the China-Korea FTA, the CETA contains stronger safeguards for the right to regulate for legitimate policy objectives, ${ }^{53}$ clarifies that regulatory change does not establish a breach of investment protection obligation, ${ }^{54}$ and includes an exemption of changes of subsidies from the investment protection obligation. ${ }^{55}$ As discussed below, the ChAFTA contains rules that are more advanced (e.g. the public welfare notice) or favorable (e.g. the broad exclusion of measures from ISDS) regarding regulatory space.

The ChAFTA is much stronger than other Chinese FTAs in preserving regulatory autonomy, some of which are innovative. To safeguard the right to regulate, it provides for the narrow scope of ISDS mechanism and the related public welfare notice, as well as the governing law of ISDS.

A wide range of claims are excluded from ISDS under the ChAFTA, which involves investment screening, regulatory measures, subsidies, and grants. Among them, claims related to foreign investment screening, such as the review by the Foreign Investment Review Board (FIRB), are exempted from the ISDS mechanism. ${ }^{56}$ The ChAFTA further stipulates that subsidies or grants provided by treaty parties fall outside the scope of its investment chapter. ${ }^{57} \mathrm{In}$ the same context, the China-Korea FTA only excludes current measures concerning subsidies or grants from the application of treatment for the cases of civil strife, ${ }^{58}$ and they should be subject to other investment rules.

As a carve-out for regulatory measures, non-discriminatory measures for legitimate public welfare objectives (i.e. health, safety, environment, public morals or order) are not subject to the IsDs claims under the ChAFTA. ${ }^{59}$ If the respondent deems that its disputed measure falls within such a carve-out, it could deliver a notice elaborating the basis for its position to the claimant and non-disputing party, which is referred to as the public welfare notice. ${ }^{60}$ Significantly, the public welfare notice serves as an important safeguard for

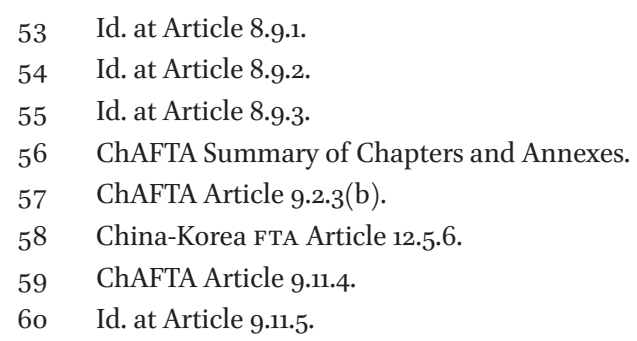


regulatory autonomy and is absent in China's previous FTAs. This notice will lead to a 9o-day consultation between the respondent and non-disputing party, during which the dispute resolution procedure will be suspended. ${ }^{61}$ If the FTA parties decide that the challenged measure falls within the scope of the exception, the decision is binding on the IsDs tribunal regarding its decision or award. ${ }^{62}$ Neither the non-issuance of a public welfare notice nor the absence of a joint decision by the treaty parties lends support to the tribunal for the adverse inference. ${ }^{63}$ As an important and novel safeguard for regulatory space, the public welfare notice grants more control to governments and evokes more deference of public interests when warranted. Therefore, the support of the home country will be necessary for the claimant in such context as both governments may block the ISDS claims.

Relating to this, the ChAFTA goes beyond the China-Korea FTA, CETA and TPP concerning regulatory autonomy in relation to expropriation and performance requirements. All of these other agreements exempt nondiscriminatory regulatory measures for lawful public welfare objectives (e.g. public health, safety, and environment) from the indirect expropriation obligation. ${ }^{64}$ The TPP also exempts these measures from certain performance requirements with the conditions similar to the chapeau of the GATT provision on general exceptions. ${ }^{65}$ In contrast, the ChAFTA does not provide for expropriation and performance requirements, and investors, therefore, cannot rely on these provisions against regulatory measures under the FTA. Regarding governing law, the ChAFTA requires the ISDS arbitration tribunal to take into account the law of the respondent when "relevant and appropriate."66 One may argue that domestic law may be the governing law and carry more weight in supporting regulatory autonomy. Under the TPP, the national law of the respondent, including rules on the conflict of laws, could be the applicable law when conditions are met. ${ }^{67}$ The national law of the respondent may be considered as a factual matter in the TPP and CETA. ${ }^{68}$ However, the China-Korea

\footnotetext{
$61 \quad$ Id. at Article 9.11.6.

62 Id. at Article 9.18.3.

63 Id. at Article 9.11.8.

64 China-Korea FTA Annex 12-B, paragraph 3(b); TPP Annex 9-B, paragraph 3(b); CETA Annex 8-A, paragraph 3 .

65 TPP Article 9.10.3(h).

66 ChAFTA Article 9.18.1.

67 TPP Article 9.25.2(b)(i).

68 Id. at Article 9.25, footnote 34; CETA Article 8.31.2.
} 
FTA and CETA do not have explicit provisions regarding the domestic law of the respondent.

\subsection{ISDS}

China appears to be more accommodating of ISDS rules than other investment provisions (e.g. the standard of compensation for expropriation). More malleability is revealed in China's agreements with Australia and Korea. For the structure, the ChAFTA attaches a lot of importance to the IsDs stipulations and devotes one of the two sections on investment to ISDs, while the China-Korea FTA only contains one article on the ISDS. For specific obligations, the ChAFTA sets more detailed rules for (e.g. the code of conduct for arbitrators) and stricter limits on (including a public welfare notice) arbitration tribunals. The flexibility can be found in both technical (e.g. the consolidation of ISDS proceedings) and fundamental (such as treaty parties' control on ISDS) provisions on investment dispute settlement.

Foremost, compared with the China-Korea FTA, the ChAFTA ensures that treaty parties get more control over ISDS through, inter alia, the scope of the claims, the selection and disciplines of the arbitrators, as well as the interpretation and guidance by treaty parties. Most of them are absent or less developed in the China-Korea FTA.

Arbitration claims under the ChAFTA are limited to the violation of national treatment. ${ }^{69}$ It narrows the basis for the ISD s claim, and such limitation is absent in China's FTAs with Korea and New Zealand, ${ }^{70}$ the CETA, ${ }^{71}$ and TPP. ${ }^{72}$ Concerning investment rule interpretation, the parties to the ChAFTA may take the initiative in interpreting rules or interpret rules upon request. The ChAFTA parties could issue a joint decision to declare their interpretation of the FTA provision, which will bind the ISDs tribunals in ongoing and future cases. ${ }^{73}$ On request of the respondent, the tribunal shall seek the interpretation of annexes by the parties regarding whether a challenged measure fits with the scope of an entry in Section A or B of its schedule of non-conforming measures in Annex III. ${ }^{74}$ The interpretation will be made in the form of a joint decision within 90 days after the request from the tribunal. ${ }^{75}$ Such interpretation

\footnotetext{
69 ChAFTA Article 9.12.2.

$70 \quad$ China-Korea FTA Article 12.12.1, 12.12.3; China-New Zealand FTA Articles 152, 153.

71 CETA Article 8.18.1.

72 TPP Article 9.19.1.

73 ChAFTA Article 9.18.2.

74 Id. at Article 9.19.1.

75 Id. at Article 9.19.1
} 
is binding on the tribunal in current and future cases. ${ }^{76}$ The China-Korea FTA does not provide for such interpretation, under which the Joint Commission may "seek to resolve differences that may arise regarding the interpretation or application of this Agreement." ${ }^{77}$ The interpretation of investment rules by the parties is possible under the TPP and CETA through a Trans-Pacific Partnership Commission ${ }^{78}$ and the CETA Joint Committee. ${ }^{79}$

Notably, some of the ChAFTA stipulations are innovative, including the roster of arbitrators and the code of conduct for arbitrators. ${ }^{80}$ Within two years after the effective date of the agreement, the ChAFTA Committee on Investment will establish a roster of ISDS arbitration panelists that consists of at least 20 individuals. ${ }^{81}$ For such a panelist list, each country will select not less than five people and also jointly choose at least ten individuals as the tribunal chairperson who are not nationals of the ChAFTA countries. ${ }^{82}$ The roster of arbitrators enables the treaty parties to choose ISDS adjudicators.

Second, the ChAFTA strives to rest the public concern over the ISDS process by providing more advanced stipulations than the China-Korea FTA. The focus seems to be transparency, the rules of interpretation, the consolidation of the ISDS arbitration proceedings, and the possible appeal system. The ChAFTA provides for the consolidation order for multiple claims with a common legal or factual issue or arising from the same events, ${ }^{83}$ which seems to be absent in the China-Korea FTA. This rule helps to improve the efficiency, consistency, and predictability of the ISDS process.

As the ISDS procedure is criticized as being opaque, the ChAFTA emphasizes the transparency of the proceedings. Under the China-Canada Biт, the ISDS arbitration award must be publicly available. ${ }^{84}$ The ChAFTA further requires the publicity of the consultation request, the notice of arbitration, as well as the orders, awards, and decisions of the IsDs tribunal. ${ }^{85}$ Moreover, three categories of documents may be publicly available under the ChAFTA if certain conditions are met: (i) the disputing parties' pleadings, memorials, and briefs submitted to the tribunal, as well as written submissions presented in the

\footnotetext{
$76 \quad$ Id. at Article 9.19.2, 9.19.3.

77 China-Korea FTA Article 19.2.1(e).

78 TPP Article 9.25.3, 27.2.2(f).

79 CETA Article 8.31.3.

8o ChAFTA Annex 9-A.

81 Id. at Article 9.15.5.

82 Id. at Article 9.15.6.

83 Id. at Article 9.21.

84 China-Canada Bıт Article 28.1.

85 ChAFTA Article 9.17.2(a).
} 
consolidation of arbitration, (ii) minutes or transcripts of tribunal hearings, and (iii) written submissions by the non-disputing party. ${ }^{86}$ More progress in this regard is envisaged. Both parties agree to, within one year of the entry into force of the FTA, consult on the application of the United Nations Commission on International Trade Law (UNCITRAL) Rules on Transparency in Treatybased Investor-State Arbitration to ISDS arbitrations. ${ }^{87}$

For the rules of interpretation, the Vienna Convention on the Law of Treaties (Vienna Convention) will be utilized by the ChAFTA and CETA in ISDS ${ }^{88}$ and the state-to-state dispute settlement (SSDS). ${ }^{89}$ It helps to enhance the predictability of the interpretation. However, neither the TPP nor the China-Korea FTA refers to the Vienna Convention in its investment chapter. The interpretation rules in the Vienna Convention are only to be used by the panel to "consider" the China-Korea FTA and the TPP in SSDS. ${ }^{90}$

The issue of appeal system merits special attention on which the EU and US have significantly different positions. China may support the appeal system in ISDS. First, as a major economy, it is possible that a Chinese judge will serve in such an ISDS system, as is the case with the wTO dispute settlement system. Second, the appeal system arguably helps to produce more predictable and consistent jurisprudence on investment law than is the case with ad hoc tribunals. Third, the appeal system may be favoured by the governments as the appeal body judges are to be selected by treaty parties but not by the investors. Turning to the ChAFTA, it appears to lean towards the approach of the CETA on the possible ISDS appeal system. Within three years after the ChAFTA came into effect, the parties will commence negotiating the possible appellate review of legal issues in ISDS. ${ }^{91}$ It may follow the path of the CETA on ISDS appeal system. The China-Korea FTA does not mention the possibility of the ISDS appeal mechanism, and the TPP refers to the possible negotiations of such appeal arrangement if the appellate mechanism is developed elsewhere. ${ }^{92}$

Third, the ChAFTA also strengthens investment protection through ISDS rules favoring investors in selected areas, which differs from the China-Korea FTA. It permits investors to seek interim injunctive relief in the judicial or

86 Id. at Article 9.17.2(b), 9.17.2(c).

87 Id. Side Letter on Transparency Rules Applicable to Investor-State Dispute Settlement.

88 Id. at Article 9.18.1; CETA Article 8.31.1.

89 ChAFTA Article 15.9.1; CEtA Article 29.17.

$90 \quad$ China-Korea FTA Article 20.11.3; TPP Article 28.12.3.

91 ChAFTA Article 9.23.

92 TPP Article 9.23.11. 
administrative tribunal of the respondent. ${ }^{93}$ The ChAFTA adopts nearly the same language as the TPP, except for subjecting it to domestic law by adding the condition of "in accordance with the laws of the respondent." 94 The CETA sets out interim measures of protection, ${ }^{95}$ with arguably similar effect. However, such provision is absent in the China-Korea FTA.

Furthermore, the ChAFTA does not allow for the domestic administrative review process that is permitted in China's FTAs with Korea and New Zealand. It enables the faster ISDS processes and favors investors. Under the ChinaKorea and China-New Zealand FTAs, the responding party could require the investors to go through the domestic administrative review process before submitting to arbitration, and such review will take no longer than four months ${ }^{96}$ or three months respectively. ${ }^{97}$

Last but not least, more malleability of ISDS rules in China's FTAs is attributable to various factors. For one thing, China's FTAs are exploring their model for the ISDS. China has limited disputes in the ISDS proceedings and has not encountered enormous challenges in this respect. Furthermore, China often relies on the proposals of FTA partners. It seems that the ISDS clauses are carefully drafted in the ChAFTA during the period when Australia became more cautious about the ISDS than before.

\section{$4 \quad$ China as a Rule Follower, Shaker or Maker?}

\subsection{China as a Rule Shaker in the Short to Medium Term?}

On the one hand, China has not been a dominant norm maker concerning key investment clauses, and will probably remain as a rule shaker ${ }^{98}$ in the short to medium term. China's FTAS are affected by FTA partners and seem to build on the partners' proposals. China's FTAs with Australia and Korea provide support for such argument. Regarding investment, the China-Korea FTA and ChAFTA appear to be affected, at least to some extent, by the kORUs and Australian

\footnotetext{
93 ChAFTA Article 9.14.4.

94 TPP Article 9.21.3.

95 CETA Article 8.34.

96 China-Korea FTA Article 12.12.7.

97 China-New Zealand FTA Article 153.2.

98 The term "rule shaker" has been used to describe the role of the China in the world trade system. See Henry Gao, China's Ascent in Global Trade Governance: From Rule Taker to Rule Shaker, and Maybe Rule Maker?, in Making Global Trade Governance Work for Development: Perspectives and Priorities from Developing Countries 153-180 (Carolyn Deere-Birkbeck ed. 2011).
} 
approaches respectively. It is probably the reason why certain key investment rules in the ChAFTA substantially differ from the China-Korea FTA, including the lack of the FET obligation and the cautious attitude regarding investment protection enforceable through ISDS. Concerning ISDS, the ChAFTA is affected by the position of Australia, which has recently taken a case-by-case approach. ${ }^{99}$ In contrast, the China-Korea FTA resembles the TPP that is based on the KORUS. Furthermore, China's FTAs are not consistent in strong deference to regulatory space. Such deference could be seen in the ChAFTA (e.g. the public welfare notice, and domestic law possibly as governing law). It is probably due to the need for concluding the ChAFTA and to the concerns of Australia arising from investment disputes such as the tobacco plain package case. However, the China-Korea FTA is weaker in this respect and its investment rules are similar to those of the KORUs. In the same vein, China will probably be affected by the RCEP parties.

Its role as a rule shaker helps to explain why China has not formulated a consistent set of FTA investment clauses (e.g. ISDS, and regulatory autonomy). China's paradigm converges towards deep FTAs to a large extent, but detailed norms on investment protection (including the FET obligation) are affected by FTA partners. In spite of malleability, China's approaches to investment under FTAS with Korea and Australia are basically the same. Broadly speaking, investment stipulations of China's FTAs do not conflict with each other, and only differ in terms of their pace. The increasing level of investment protection in China's FTAs appears to be consistent. Investment liberalization is the major dissimilarity between China and developed economies (such as the us). However, such difference is to be narrowed through the Us-China BIT negotiations if they go smoothly under the new us President. In any case, the negative list approach and the pre-establishment national treatment is expected to be explored in China's FTA upgrade with Australia and Korea.

On the other hand, China is not a rule follower. It has a cautious attitude about investment liberalization or "intrusive" requirements, and modified or affected investment clauses when needed. These intrusive requirements involve, inter alia, state-owned enterprises (soes), labor, environment, and investments regarding cultural products. It seems that China prefers to progressively liberalize investment without unintended consequences.

China also demanded specific arrangements for investment issues in the FTAs. Under the ChAFTA, China demanded "a more receptive investment 
environment." 100 China secured specific arrangements in the ChAFTA to favor Chinese investment: the more liberal and higher FIRB screening threshold for non-SOE investment, and the related labor mobility for Chinese workers. Regarding China's non-SOE investment in Australia, the investment screening threshold has been substantially lifted to 1.078 billion Australian dollars from 0.248 billion Australian dollars previously. ${ }^{101}$ Moreover, the memorandum of understanding on an investment facilitation arrangement (IFA) is included in the ChAFTA. It facilitates the visa process under the IFAs, ${ }^{102}$ which is the first one of this kind provided by a developed country to China. ${ }^{103}$ This arrangement will help Chinese businesses to access the Australian market.

\subsection{China with the Potential to be a Rule Maker in the Long Term: From Selective Adaption to Selective Innovation?}

In the long run, China has the potential to be a major norm maker in investment if properly managed. First, there is an increasingly strong need to shape investment rules to protect China's outbound investment and explore overseas markets. Investment clauses may take the lead in shaping China's possible FTA model. China is reported to have become the globally top net capital exporter in 2015. ${ }^{104}$ This fact illustrates why China's investment norms in international agreements evolve rapidly. It is in China's interests to call for high-level investment clauses. Therefore, China sometimes takes an approach to investment that differs from developing countries. Such approach involves key issues such as ISDS, ${ }^{105}$ and is closer to that of developed economies.

Second, the potential role as a rule maker is possible given that investment norms are the fastest developing area of China's FTAs, and that capacity building develops fast on the part of China. Taking the ChAFTA as an example, it arguably makes more innovations in investment than other areas if one compares it with China's older trade pacts. Moreover, China will probably develop

100 Lingling He, Reassessing the China-Australia Free Trade Agreement Negotiation Process, 10 Frontiers of LAW IN China 714, 721 (2015).

101 China FTA Network, A Reading of the Free Trade Agreement Between the Government of Australia and the Government of the People's Republic of China(2016), available at http:// fta.mofcom.gov.cn/article/chinaaustralia/chinaaustralianews/201506/22176_1.html.

102 ChAFTA MOU on an Investment Facilitation Arrangement, paras 8-11 2015.

103 China FTA Network, supra note 101.

104 China becomes world's top net capital exporter (2016), available at http://www.atimes.com/ article/china-becomes-worlds-top-net-capital-exporter/.

105 Investment rules of China's recent FTA are dissimilar from India's recent BIT model. For instance, the exhaustion of remedies requirement in India's BIT model cannot be found in the ChAFTA. 
a stronger capacity in investment than other areas of FTAs, due to frequent participation in investment agreement talks. More importantly, some of the negotiations are high-level and deep (i.e. the BIT negotiations with the Us and $\mathrm{EU})$, qualities which are absent in other areas of FTAs. BIT negotiations with major economies (e.g. the US, EU, and Japan), and FTA negotiations with various partners under the framework of a bilateral or mega FTA help the capacity building of China.

Finally, challenges still exist for China, and open issues remain to be addressed. In the near future, China's role may not be as a rule maker, but could change from selective adaption to selective innovation. Such targeted innovation may first occur in high-level investment agreements and particularly the Us-China BIT.

For one thing, China will need the strong support of major economies, developing and developed ones, to lead the shaping of new investment norms. It may be a challenging job to convince partners. Furthermore, it remains to be seen whether China is prepared to accept stringent or sensitive investment stipulations (e.g. SoEs, and labor). Open questions in China's investment clauses include performance requirements, investment review by the host country, the appeal system in the ISDS, environment, labor, and soEs. Regulatory uncertainty and barriers may exist in these aspects. For instance, the TPP chapter on SOEs and designated monopolies applies concerning the activities of these enterprises that affect "investment between Parties within the free trade area." ${ }^{106}$ China's FTA investment rules have not dealt with SOE issues. Even when some of these matters are to be addressed, it may take a soft law approach such as hortatory language on the environmental issue in the China-Korea FTA. ${ }^{107}$ On a related note the SOE and other thorny or "intrusive" issues are not likely to be the major subject in the RCEP negotiations due to the different interests of RCEP parties.

China's FTA Approach to Investment and the RCEP

\subsection{Uniqueness of the RCEP and its Investment Rules}

The RCEP is unique in several aspects. First, the RCEP is special to China as the only mega FTA in which China is involved. For geopolitical considerations, China may strive to prioritize the conclusion of the RCEP rather than setting demanding requirements. China could have more incentives to compromise

\footnotetext{
106 TPP Article 17.2.1.

107 China-Korea FTA Article 12.16.
} 
on the RCEP, since it enables market access to a larger number of countries than bilateral agreement and may bring broader geopolitical effects. After the fall of the TPP, this could be the major incentive for China to move further with the RCEP, which will shape and mold the relationship with countries that otherwise would have been part of the TPP.

Second, the RCEP investment rules will probably be in a unique position given the existence of prior agreements. China has FTAs with the ASEAN, Australia, New Zealand and Korea, all of which contain investment clauses. Moreover, BITs often also exist between China and these RCEP parties (e.g. Australia, and Korea), and China also concluded an FTA with Singapore, a founding country of the ASEAN. For the rest of RCEP countries (i.e. Japan, and India), there are China-Japan-Korea and China-India investment treaties, which entered into force in 2014 and 2007 respectively. From the perspective of China, a number of generally recent agreements ${ }^{108}$ already exist between China and all other RCEP parties on a bilateral basis to deal with investment issues. The existing stockpile of investment rules could constitute "Plan B," even if the RCEP does not contain detailed clauses on investment.

Third, China appears to be more flexible in FTA negotiations with the ASEAN than other partners, and the ASEAN seems to lead the RCEP negotiations. Arguably it is basically because of geopolitical considerations. The ASEAN seems to lead the negotiations of the RCEP, which is supported by China. ${ }^{109}$ China has been quite flexible with the ASEAN in the China-ASEAN FTA, which is one of China's earliest trade pacts. Besides Pakistan, China has only granted the ASEAN full post-establishment national treatment of investment in its old FTAs. ${ }^{110}$ Additionally, the China-ASEAN FTA is the only FTA for which China used the "enabling clause" of the wTо to ensure the WTO-consistency of a lower standard FTA with developing countries.111

\subsection{The RCE P Investment Rules: Low-level Ones with an Early Harvest Approach?}

On the one hand, the RCEP may contain low-level or moderate investment norms. In the short term, China's approach to investment will remain the same

\footnotetext{
108 The exception includes China-Australia BIT, which came into force in 1988.

109 Gao Hucheng: Support the ASEAN to Lead RCEP Negotiations (2016), available at http://fta .mofcom.gov.cn/article/fzdongtai/201608/32899_1.html.

110 Nargiza Salidjanova, China's Trade Ambitions: Strategy and Objectives behind China's Pursuit of Free Trade Agreements, U.S.-China Economic and Security Review Commission Staff Research Report, 18 (2015).

111 Id. at 21.
} 
concerning the malleability of investment protection, regulatory autonomy, and ISDS. However, China is unlikely to take strict investment liberalization obligations under the RCEP. Given the uniqueness of the mega FTA, China's flexibility for the ASEAN and the existence of "back-up" agreements, China will probably facilitate the conclusion of the pact rather than demand stringent rules. Concerning investment, the RCEP will "aim at creating a liberal, facilitative, and competitive investment environment in the region" and its investment negotiations are to cover "the four pillars of promotion, protection, facilitation and liberalization."112 Due to the different interests of the parties, the RCEP could eventually focus on investment protection rather than investment liberalization.

On the other hand, the RCEP could adopt an early harvest approach with future upgrades. China has common ground with other RCEP parties, and China's FTAs are mostly consistent with the general principles and objectives of the RCEP (including the facilitation of investment and the enhancement of transparency in investment relations ${ }^{113}$ ). Such efforts could be found in the ChAFTA in facilitating investment and increasing the transparency of IsDs. China could find common ground on investment with other RCEP parties based on existing agreements, since investment or trade agreements have been concluded between China and these parties. Among the parties, the ASEAN seems to lead the RCEP negotiations, and the viewpoints reflected in China's recent investment treaty practice are largely congruous with the ASEAN practice. ${ }^{114}$

Thorny issues could be addressed at a later stage (e.g. the market access obligations for developing countries), and a forward work program may be provided in the RCEP. Such arrangement will be useful in concluding the mega FTA at an early date while leaves the possibility for its upgrade. In other words, there is a second chance to negotiate the FTAs. However, the upgrade of mega FTA will be much harder than bilateral ones given a large number of countries involved and their different positions. That said, the upgrades of FTAs also give China and other parties more flexibility to chart its course.

The early harvest approach and upgrade arrangement are not rare for China's FTAS. In contrast, the FTAS of the US and EU do not usually upgrade

\footnotetext{
112 Guiding Principles and Objectives for Negotiating the Regional Comprehensive Economic Partnership, available at http://dfat.gov.au/trade/agreements/rcep/Documents/guidingprinciples-rcep.pdf.

113 Guiding Principles and Objectives for Negotiating the Regional Comprehensive Economic Partnership, available at http://dfat.gov.au/trade/agreements/rcep/Documents/guidingprinciples-rcep.pdf.

114 Feldman, et al., supra note 15, at 9.
} 
despite such possibilities. The China-ASEAN FTA is the first upgraded FTA of China, but it contains limited progress regarding rule development. The ChinaKorea FTA provides for the plan of subsequent investment negotiations. The ChAFTA investment clauses also adopt a two-stage approach: early harvest commitments and a future work program (e.g. expropriation, performance requirements). The ChAFTA parties agree on "a review of the investment legal framework between them" within three years after the pact enters into force, ${ }^{115}$ and will eventually start negotiating on a "comprehensive" investment chapter. ${ }^{116}$ Therefore, the ChAFTA allows treaty parties to negotiate piecemeal for more investment liberalization. The ChAFTA model may be adopted for the RCEP as a work-in-progress type investment chapter. As the case with the ChAFTA, one possible arrangement under the RCEP could be that developed countries but not developing countries commit to market access provisions (e.g. pre-establishment national treatment obligations) at the very beginning.

\section{Conclusion}

Foremost, the malleability of China's FTAs will probably expand from investment protection to investment liberalization, and increased malleability of China's recent FTAs exists in regulatory autonomy and ISDS. This is because China's FTAs are largely adapted to the need of trading partners. China's recent agreements with Australia and Korea are seen as having a high degree of malleability. Overall, China's approach to investment protection is similar to deep FTAS with some exceptions (e.g. performance requirements, the standard of compensation in expropriation, the scope of MFN treatment and the scope of ISDS claims).

Generally, China is willing to substantially improve rules and embrace newer-style investment stipulations. As a typical example, the Us-China BIT negotiations reflect China's new development of investment liberalization. The ChAFTA contains innovative safeguards of regulatory autonomy and ISDS procedural features (including the roster of arbitration panelists, the public welfare notice, the code of conduct for arbitrators, and the joint interpretation of the annex by treaty parties).

\footnotetext{
115 ChAFTA Article 9.9.1.

116 Id. at Article 9.9.3.
} 
Second, China will probably be a rule shaker in the short to medium term, and possibly become a rule maker in the long term. Its approach may evolve from selective adaption to targeted innovation. The reason is plain as China will be increasingly active in the development of investment norms due to the need to protect its outbound investment and enhance investor confidence in inbound investment. As a rule shaker, China may often modify proposals of partners rather than offer a new set of clauses.

Finally, the RCEP investment rules will possibly be low-level ones with an early harvest approach. It is due to, among other things, the unique nature of mega FTA, the "stockpile" of existing investment agreements, and China's approach to the ASEAN. All these factors mean that China will probably take a more flexible stance in the RCEP than in bilateral FTAs. In any event, the RCEP will significantly affect the shaping of China's FTA approach to investment. 